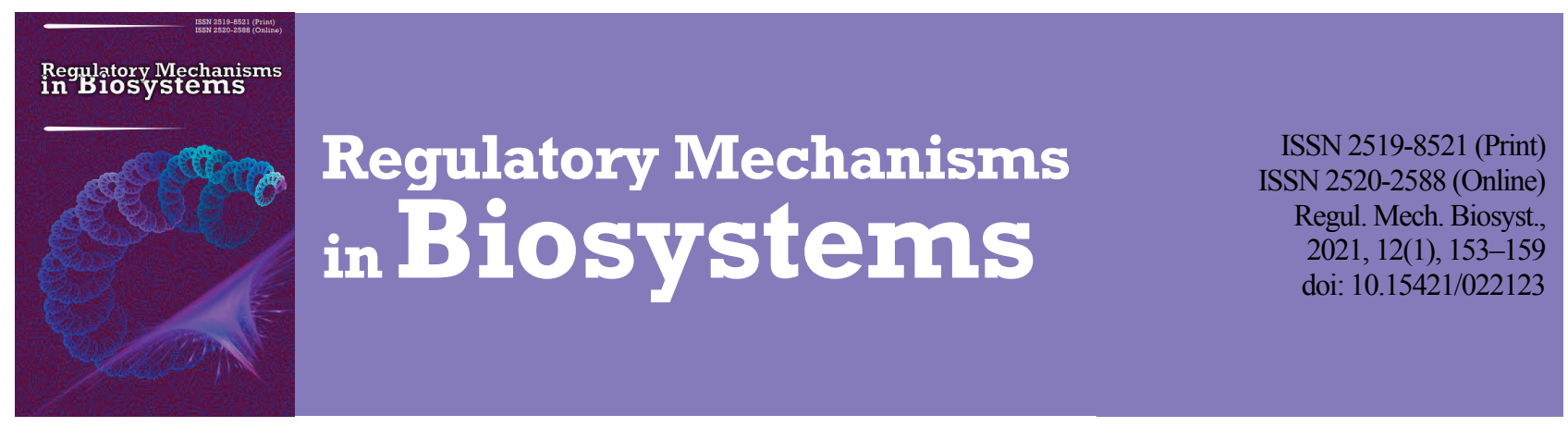

\title{
Features of modern winter wheat varieties in terms of winter hardiness components under conditions of Ukrainian Forest-Steppe
}

\author{
A. V. Pirych*, T. V. Yurchenko*, V. M. Hudzenko*, O. A. Demydov*, \\ H. M. Kovalyshyna**, O. V. Humeniuk*, V. V. Kyrylenko* \\ *The V. M. Remeslo Myronivka Institute of Wheat of the National Academy of Agrarian Sciences of Ukraine, Kyiv region, Ukraine \\ **National University of Life and Environmental Sciences of Ukraine, Kyiv, Ukraine
}

Article info

Received 10.02.2021

Received in revised form 15.03 .2021

Accepted 16.03.202

The V.M. Remeslo Myroniv$k a$ Institute of Wheat of

National Academy

of Agrarian Sciences

of Ukraine, Tsentralna st., 68

Tsentralne village,

Myronivka district, Kyi

region, 08853, Ukraine.

Tel.: +38-097-749-98-91.

E-mail:

alina22pirych@gmail.com

National University of Life and Environmental Sciences of Ukraine, Heroiv Oboron st, 15, Kyiv, 03041, Ukraine. $\mathrm{Tel} \cdot \mathbf{+}+38-096-410-45-16$ E-mail:

hkovalyshyna@gmail.com

Pirych, A. V., Yurchenko, T. V., Hudzenko, V. M., Demydov, O. A., Kovalyshyna, H. M., Humeniuk, O. V., Kyrylenko, V. V. (2021). Features of modern winter wheat varieties in terms of winter hardiness components under conditions of the Ukrainian Forest-Steppe. Regulatory Mechanisms in Biosystems, 12(1), 153-159. doi:10.15421/022123

In recent years, there has been a significant change in climatic conditions affecting the cultivation and yield of winter wheat. Therefore, the creation of wheat varieties with high adaptive potential is one of the main tasks of modern breeding. A significant component of the overall adaptive potential of winter wheat is winter hardiness, which is determined by a set of characters enabling plants to overwinter. To a large extent, winter hardiness is determined by gene systems that control vernalization requirement duration, photoperiod reaction, and frost resistance. The research is aimed at determining the features of modern winter wheat varieties developed at the V. M. Remeslo Myronivka Institute of Wheat of the National Academy of Agrarian Sciences of Ukraine in terms of winter hardiness components and adaptive potential in the environment of the Central part of the Ukrainian Forest-Steppe. Winter bread wheat varieties Estafeta myronivska, Hratsiia myronivska, MIP Assol, and Balada myronivska were studied. They also were crossed on incomplete diallele scheme with three near-isogenic lines derived from Erythrospermum 604 with different alleles of Vrd genes 1) Vrd1Vrd1vrd2vrd2, 2) vrdlvrd1Vrd2Vrd2, and 3) vrdlvrdlvrd2vrd2. It was established that vernalization requirement duration in the varieties Estafeta myronivska and Balada myronivska was short whereas in the varieties Hratsiia myronivska and MIP Assol it was medium. All the varieties studied have medium photoperiod sensitivity. The results of the hybridological analysis indicate the absence of the Vrd1 and Vrd2 genes in the varieties. Frost tolerance of these varieties is at the same level and higher than in the highly tolerant to the low temperatures variety Myronivska 808. Thus, the results indicate the possibility of recombining different levels of expression of these traits in genotypes by breeding efforts. This has great practical importance in farming, because in recent years the areas of crops harvested late (corn, sunflower, etc.) in the production conditions has significantly increased. It causes a shift in sowing dates of winter wheat to a later period. In this case, varieties Estafeta myronivska, Hratsiia myronivska, MIP Assol, and Balada myronivska are able to undergo sufficient hardening, to satisfy the vernalization requirement, and to form a high level of winter hardiness. Their relatively medium photoperiod sensitivity allows vegetation to be restored a little earlier in the spring and winter reserves of moisture to be used more effectively

Keywords: Triticum aestivum; frost tolerance; vernalization requirement; photoperiod sensitivity; hybridological analysis.

\section{Introduction}

In recent years, there has been a significant change in climatic conditions affecting the cultivation and yield of winter wheat (Kristensen et al., 2011; Blyzniuk et al., 2019). Therefore, the creation of varieties with increased adaptive potential is one of the priority tasks of winter wheat breeding today (Rybas et al., 2018). Winter hardiness is one of the main components of the general adaptive potential of winter wheat (Sandve et al., 2010). Genetic systems associated with winter hardiness include the genes determining plant response to vernalization $(\mathrm{Vrn})$, photoperiod sensitivity (Ppd) and frost resistance (Fr) (Sutka, 2001; McIntosh et al., 2013; Kiss, 2014).

Wheat photoperiod sensitivity is plant response to daylength expressed in the delay of heading date in photoperiod sensitive genotypes when daylength is shortening. The genes Ppd-A1, Ppd-B1, Ppd-D1 which control photoperiod sensitivity are located on the chromosomes 2A, 2B, 2D, respectively (Law et al., 1978; Worland et al., 1998). Variation in photoperiod sensitivity is a factor that leads to variability of adaptability and productivity of winter wheat varieties. Low responsiveness to the daylength reduction in the majority of varieties is due to the presence of the dominant allele Ppd-D1a in their genotype (Fayt et al., 2014). Varieties with dominant allele of the Ppd-D1 gene were less tolerant to low temperatures as compared to plants with an alternative recessive allele (Toptikov \& Chebotar, 2019).

Vernalization is prolonged exposure to low temperatures which induces the transition of winter crops from the vegetative to the generative stage of development (Deng et al., 2015). The combination of different dominant alleles of Vrn loci affects the heading date and, accordingly, duration of the whole growing season (Stelmakh, 1993). It has been shown that the mechanism for determining sensitivity to vernalization and heading date is based on mutations in the Vrn gene loci which correct the dependence of the transition to heading stage on the vernalization factor and transmit the gene from recessive into dominant (Distelfeld et al., 2009). More prolonged vernalization requirement leads to slower development in the initial stages of organogenesis, so the transition to formation of differentiated growth point and primordia of reproductive organs in such genotypes occurs much later (Prasil et al., 2004). The reduction of the vernalization duration may lead to an earlier transition of the plant from dormancy in spring and winter during thaws, which causes the reduction of winter hardiness and frost resistance. Sometimes it has significant negative influences on the grain yield (Fayt, 2003; Koemel et al., 2004). The winter type of development is manifested when the three major Vrn 
genes are represented by recessive alleles. However, the presence of only one dominant allele of $\mathrm{Vm}$-A1 gene provides complete insensitivity of plants to vernalization. Dominant alleles of the Vrn-B1 and Vrn-D1 loci only partially reduce the vernalization requirement (Pugsley, 1971; Pugsley, 1972). Genes determining plant growth habit are localized on different chromosomes: Vm-A1 (previous designation Vm1) on 5A, Vm-B1 (Vm2) on 5B, Vm-D1 (Vm3) and Vrn-D4 (Vrn4) on chromosome 5D. The Vm-B3 gene (earlier Vm5) is located in the short arm of chromosome 7B (Worland, 1996; Yan et al., 2006; Yoshiba et al., 2010). The efficacy of Vm and Ppd gene alleles marking for early diagnosis of plant response to vernalization and photoperiod has been reported (Cockram et al., 2009; Yang et al., 2009). The study of the duration of the stages of development of winter bread wheat in isogenic and substituted lines with different alleles of Vrn1 genes suggests that growing season duration depends mainly on the duration of period "tillering-the first node" (Pankova \& Kosner, 2004; Emtseva et al., 2013). Stelmakh et al. (2005) reported the identification of three vernalization requirement duration genes of winter wheat, designated by authors as Vrd1, Vrd2, and Vrd3. The Vrd1 gene is located on chromosome $4 \mathrm{~A}, \mathrm{Vrd} 2$ is on chromosome 5D. It was found that presence of dominant gene Vrdl reduces the vernalization requirement duration to 20-35 days, depending on the photoperiod sensitivity of the variety, and Vrd2 does to $40-45$ days (Balashova et al., 2006). Genotypes with recessive alleles of two Vrd genes (vrd1vrd1vrd2vrd2) require at least 50-60 days of vernalization for transition from the vegetative to the generative stage of development. A third gene (Vrd3) is also thought to be present, which determines the duration of vernalization up to 40 days and is located on one of the chromosomes 1A, 6A, or 4B (Fayt et al., 2007). Other scientists suggest that vernalization requirement duration is determined by changes in a locus of the Vrn-A1 gene (Yan et al., 2015) or Vrn-B1 (Guedira et al., 2013). It has also been suggested that the trait vernalization requirement duration in winter wheat may be controlled by the TaVRN-A1 gene at the protein level (Li et al., 2013). The study of the effects of genes controlling the vernalization duration (Vrd) on agronomic traits in isogenic lines of winter wheat shows that the dominant alleles of the genes Vrd1 and Vrd2 cause reduction in plant height as well as the shortening of the period to heading as compared to carriers of only recessive alleles of the gene vrd1vrd2 (Fayt, 2007).

Frost tolerance is the ability of plants to withstand negative temperatures during wintering (Sutton et al., 2009). Genes associated with freezing tolerance of winter wheat Fr1 and Fr2 are localized on chromosomes 5A and 5D, respectively (Sutka, 2001). It is assumed that the presence of the Vrn-D1 and Fr-D1 genes in the wheat genotype not only determines the level of freezing tolerance, but also plant resistance to snow mold (Francia et al., 2007; Erath et al., 2017).

Given the above, to characterize modern genotypes of winter wheat on genetic systems that determine the processes of vernalization, photoperiod sensitivity, frost resistance and their impact on growth, development and general adaptive potential is relevant (Bakuma, 2016; Fayt et al., 2017; Jones et al., 2017). It was found that under various agroclimatic conditions there are different combinations of vernalization requirement and photoperiod sensitivity in winter wheat genotypes, which leads to increased adaptive potential, in particular, frost resistance (Whittal et al., 2018; Kawakita et al., 2020; Royo et al., 2020).

The aim of the research was to identify the features of modern varieties of winter wheat developed at the V. M. Remeslo Myronivka Institute of Wheat of the National Academy of Agrarian Sciences of Ukraine (MIW) by vernalization requirement, photoperiod reaction and frost resistance as components of winter hardiness and adaptive potential in the Central part of Ukrainian Forest-Steppe.

\section{Materials and methods}

The research was conducted in 2016-2019 at the MIW. We used new Myronivka winter wheat varieties (Estafeta myronivska, Hratsiia myronivska, MIP Assol and Balada myronivska) which are included in the State Register of Plant Varieties Suitable for Dissemination in Ukraine since 2018. When analyzing the pedigrees of these varieties, it was established that the varieties Estafeta myronivska and Hratsiia myronivska were created on the basis of crossing local varieties and lines with each other while in creating the varieties Balada myronivska and MIP Assol, collection samples of different ecological origin from Hungary and Russia were used (Table 1).

Table 1

Genealogical characteristics of the studied winter wheat varieties

\begin{tabular}{|c|c|}
\hline $\begin{array}{c}\text { Variety, } \\
\text { biological variety }\end{array}$ & Genealogy \\
\hline $\begin{array}{c}\text { Estafeta } \\
\text { myronivska } \\
\text { (var. lutescens) }\end{array}$ & $\begin{array}{l}\text { Myronivska } 64 \text { [Myronivska yuvileina (Lutescens106/ Bezos- } \\
\text { taya 4) / KM 66-10-1-79] / Lutescens } 50713 \text { \{Myronivska } 27 \\
\text { [Lutescens } 6915 \text { (Prybii / Myronivska yuvileina) / Lutescens } \\
6538 \text { )] / Nike\} }\end{array}$ \\
\hline $\begin{array}{l}\text { Hratsiia } \\
\text { myronivska } \\
\text { (var. } \\
\text { erythrospermum) }\end{array}$ & $\begin{array}{l}\text { Erythrospermum } 52422 \text { [Erythrospermum } 9736 \text { (Narino } 59 \text { / } \\
\text { Veneda)] / Erythrospermum 52687 from Erythrospermum } \\
10071 \text { \{Erythrospermum } 5226 \text { [WRH* k-43822 / Lutescens } \\
2274 \text { (Lutescens } 106 \text { / Bezostaya } 4 \text { // Bezostaya 4)] / Lutescens } \\
6075\} \text { / Gama// Donskaya intensivnaya }\end{array}$ \\
\hline $\begin{array}{c}\text { MIP Assol } \\
\text { (var. lutescens) }\end{array}$ & $\begin{array}{l}\text { Sakwa / Myronivska } 65 \text { \{Myronivska 61 [Illichivka(Bezostaya } 4 \\
\text { / Myronivska 808) / Hadm. 6508-74)] / Myronivska } 27 \\
\text { [Lutescens 6915 (Prybii / Myronivska yuvileina) / Lutescens } \\
6538 \text { (Hadm. 6508-74)]\} // Lutescens } 52948 \text { \{Lutescens } 2060 \\
\text { from Myronivska } 27 \text { [Lutescens } 6915 \text { (Prybii / Myronivska } \\
\text { yuvileina) / Lutescens 6538]\} / Myronivska } 61 \text { [Illichivka (Be- } \\
\text { zostaya } 4 \text { / Myronivska 808) / Hadm. 6508-74] / Lutescens } \\
\text { 20051 \{Myronivska } 61 \text { [Illichivka (Bezostaya } 4 \text { / Myronivska } \\
\text { 808) / Hadm. 6508-74]\} / NS 954 / Kavkaz // Rezo / Lutescens } \\
\text { 8133 [Siete Cerros } 66 \text { / Myronivska yuvileina (Bezostaya } 4 \text { / } \\
\text { Myronivska 808)] }\end{array}$ \\
\hline $\begin{array}{l}\text { Balada } \\
\text { myronivska } \\
\text { (var. erythrosper- } \\
\text { mum) }\end{array}$ & $\begin{array}{l}\text { Donskaya polukarlikovaya / Estet (Illichivka / SK-2542, CZE // } \\
\text { CIMMYT-151) / Erythrospermum } 10071 \text { \{Erythrospermum } \\
5226 \text { [WRH k-43822 / Lutescens } 2274 \text { (Lutescens 106/ Bezos- } \\
\text { taya } 4 \text { // Bezostaya 4)] / Lutescens } 6075\} \text { // Erythrospermum } \\
53321 \text { [Lutescens } 9950 \text { (Illichivka / SK-2542 // CIMMYT-151)] } \\
\text { / Erythrospermum } 10071 \text { \{Erythrospermum 5226 [WRH k- } \\
\text { 43822 / Lutescens } 2274 \text { (Lutescens } 106 \text { / Bezostaya } 4 \text { // Bezos- } \\
\text { taya 4)]/ Lutescens 6075\} }\end{array}$ \\
\hline
\end{tabular}
Note: *WRH-wheat-rye hybrid.

To determine photoperiod sensitivity of the winter wheat varieties two variants of the experiment were laid: in the first the plants were grown under natural daylight; in the second they were under artificially shortened daylight (12 hours). Before sowing, the germinated seeds were artificially vernalized for 60 days (at $0 \ldots+1^{\circ} \mathrm{C}$ ). Using a special marker, germinated seeds of each variety were planted 20 pcs in each of two vegetative pots per variant of the experiment. Then the pots were placed in an open area. To shorten day length, the plants in the pots were covered with black boxes (Fig. 1a). The date of heading occurrence for individual plants was marked with labels (Fig. 1b). According to photoperiod sensitivity, wheat varieties were divided into three groups: high-, medium- and low sensitive. In our experiment, the first group included varieties that responded to the daylight reduction with significant heading delay of 10-13 days, the second group with delay of 6-9 days, and the third group with less than 6 days.

To determine vernalization requirement duration, 100 seeds of each variety were watered and placed for germination in a thermostat at the temperature of $+19 \ldots+20^{\circ} \mathrm{C}$ for one day. To go through vernalization, the seedlings were placed in the LVN-200G chamber at the temperature of $0 \ldots+1{ }^{\circ} \mathrm{C}$ for different periods $(50,40$, and 30 days). The vernalized seedlings were planted in spring at a time when the level of long-term air temperature avoids additional vernalization of experimental samples in the field (for the research period it was on April 14-18). Previously, the field was divided into strips of width $1 \mathrm{~m}$ and tracks between strips of $50 \mathrm{~cm}$. The seedlings were planted on two rows for each variant of the experiment, about 50 seeds per row. The plants were counted in early August using the envelope method. The duration of the vernalization period was considered to be sufficient if the most plants of the variety reached heading.

As testers that allow to one establish differences in wheat plant development at early stages of organogenesis we used near-isogenic by genes Vrd winter wheat lines Erythrospermum 604 Vrd1Vrd1vrd2vrd2, Erythrospermum 604 vrd1vrd1Vrd2Vrd2, Erythrospermum 604 vrd1vrd1vrd2vrd2 created at the Plant Breeding and Genetics Institute National Center of Seed and Cultivar Investigation of NAAS (Fayt, 2006). 

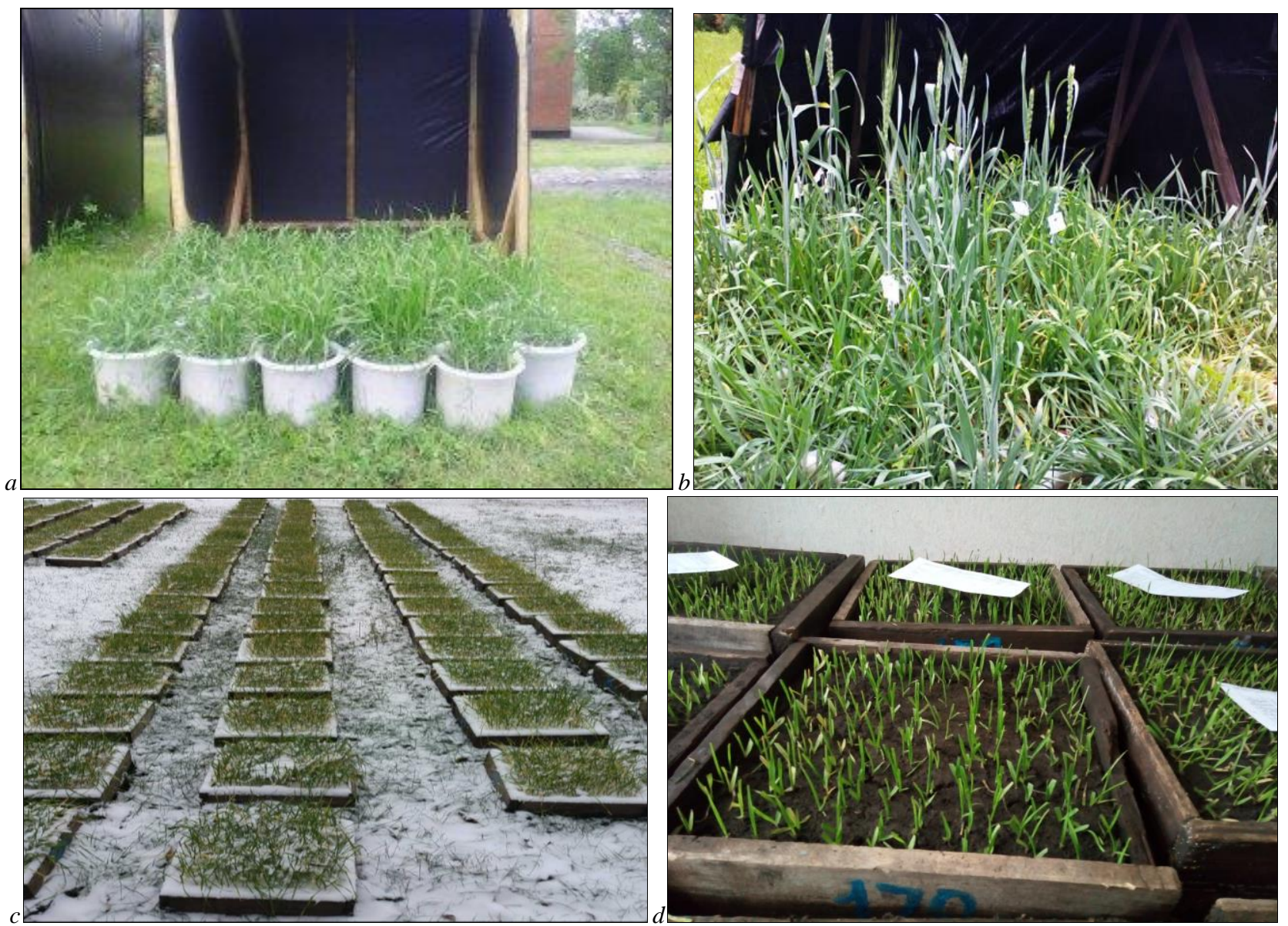

Fig. 1. Photoperiod sensitivity and frost tolerance evaluation: $a$ - winter wheat plants photoperiod shortening with black boxes;

$b$-labeling of the heading occurrence of individual plants; $c$-sowing boxes with winter wheat plants in natural conditions where the first and second stages of hardening took place; $d$ - winter wheat plants' regrowth after the freezing

The varieties and testers were crossed according to the incomplete diallel scheme with twirl-method of female plant pollination. The F1 seeds obtained were sown in autumn for reproduction of genetic material. F2 seeds were vernalized for 40 and 30 days. To establish differences in Vrd genes, the plants of each hybrid population were divided into two phenotypic classes according to the ratio "heading occurrence: no heading occurrence" (Syvolap \& Balashova, 2007).

In order to evaluate freezing tolerance of winter wheat varieties special sowing boxes were used. The sowing boxes measuring $30 \mathrm{x} 40 \mathrm{~cm}$ and $12-15 \mathrm{~cm}$ deep were filled with ordinary sieved soil to $3-4 \mathrm{~cm}$ below the top edge. The soil surface was leveled and marked in rows. The experimental material was planted in sowing boxes in rows every $3-4 \mathrm{~cm}, 20$ 25 seeds in each row. The top was covered with soil for $3 \mathrm{~cm}$. In each box there were also planted two rows of the standard variety Myronivska 808 with high frost resistance. The whole period of autumn and early winter the plants were under natural conditions (Fig. 1c), where the first and second stages of hardening took place. Plant care consisted of regular watering. Due to the fact that freezing tolerance of winter crops not only has seasonal dynamics (increases in autumn, in mid-winter is the highest and decreases sharply in spring), but also strongly depends on the specific conditions of hardening in different years, the freezing was carried out at two temperatures: -18 and $-20{ }^{\circ} \mathrm{C}$. The sowing boxes were transported from the open vegetation area and placed in low-temperature chambers $(\mathrm{KNT}-1 \mathrm{M})$. Freezing was performed at two temperatures, starting to decrease the temperature in the chambers from ambient temperature by $2{ }^{\circ} \mathrm{C}$ every hour (down to -18 and $-20^{\circ} \mathrm{C}$ ) and with freezing exposure being 24 hours. After gradual thawing, the sowing boxes were placed in a room with temperature of $+18 \ldots+24{ }^{\circ} \mathrm{C}$ and winter wheat plants were prepared for regrowth. The plants' leaves were trimmed down to $0.5 \mathrm{~cm}$ long. The counting of preliminary viable and frost-killed plants was carried out in 10-12 days (Fig. 1d), and the final counting was in 15-16 days.

The data were analyzed using Statistica 12.0 (StatSoft Inc., USA) program. Tables 2, 3, 4 and 6 demonstrate the results as $\mathrm{x} \pm \mathrm{SE}(\mathrm{x} \pm$ stand- ard error). Differences between the values of the experimental variants were determined using the ANOVA with consideration of Bonferroni correction, where the differences were considered significant at $\mathrm{P}<0.05$. Hybridological analysis was performed in $\mathrm{F} 2$ populations by the comparison of the fact segregation of the plant phenotypes' number with theoretically expected using chi-square $\left(\chi^{2}\right)$ criterion (Table 5).

\section{Results}

Photoperiod sensitivity. The maximum vernalization duration is sufficient for all genotypes and thus neutralizes the diversity for days from planting to heading, which is determined by the system of the Vrd genes. Insufficient vernalization, on the contrary, allows such diversity to be revealed, and the difference between vernalization duration at cultivation in the extended (natural) photoperiod, characterizes the degree of the response to vernalization by heading acceleration or delay. Similarly, the extended photoperiod at the III-V stages of organogenesis eliminates the diversity in photoperiodic sensitivity, while the shorter daylight helps to detect it (Stelmakh \& Herasymenko, 2008). Given the above, the difference in days to heading between the variants of the experiment (natural and shortened photoperiod) determines the photoperiodic sensitivity of plants, which is manifested in the delay or acceleration of the period to heading. The greatest number of days to heading was observed in 2018, and the lowest was in 2016 (Table 2).

Variation was noted in days to heading between the variants of the experiment in varieties of Myronivka breeding in different years of the research. In the variety Estafeta myronivska the difference was 6.59.2 days, in Hratsiia myronivska it was 6.8-10.1 days, in MIP Assol 4.79.8, in Balada myronivska 4.7-13.6.

Thus, it was found that all new varieties of winter bread wheat (Estafeta myronivska, Hratsiia myronivska, MIP Assol, Balada myronivska) in terms of the photoperiodic sensitivity belong to the group with relative medium photoperiodic sensitivity. 
Table 2

Days to heading under the natural and shortened photoperiod in new varieties of winter wheat $(x \pm S E, n=30)$

\begin{tabular}{lllllll}
\hline \multirow{2}{*}{ Variety } & \multicolumn{2}{c}{2016} & \multicolumn{2}{c}{2017} & \multicolumn{2}{c}{2018} \\
\cline { 2 - 7 } & $\begin{array}{c}\text { natural } \\
\text { photoperiod }\end{array}$ & $\begin{array}{c}\text { shortened } \\
\text { photoperiod }\end{array}$ & $\begin{array}{c}\text { natural } \\
\text { photoperiod }\end{array}$ & $\begin{array}{c}\text { shortened } \\
\text { photoperiod }\end{array}$ & $\begin{array}{c}\text { natural } \\
\text { photoperiod }\end{array}$ & $\begin{array}{c}\text { shortened } \\
\text { photoperiod }\end{array}$ \\
\hline Estafeta myronivska & $51.0 \pm 0.5^{\mathrm{a}}$ & $58.4 \pm 1.0^{\mathrm{a}}$ & $55.0 \pm 0.2^{\mathrm{a}}$ & $61.5 \pm 0.3^{\mathrm{a}}$ & $59.5 \pm 1.3^{\mathrm{a}}$ & $68.7 \pm 1.7^{\mathrm{a}}$ \\
Hratsiia myronivska & $48.8 \pm 0.4^{\mathrm{b}}$ & $55.9 \pm 1.1^{\mathrm{b}}$ & $51.9 \pm 0.2^{\mathrm{b}}$ & $58.7 \pm 0.6^{\mathrm{b}}$ & $53.0 \pm 1.3^{\mathrm{b}}$ & $63.1 \pm 1.9^{\mathrm{b}}$ \\
MIP Assol & $51.8 \pm 0.4^{\mathrm{a}}$ & $57.5 \pm 0.4^{\mathrm{ab}}$ & $55.5 \pm 0.3^{\mathrm{a}}$ & $65.3 \pm 0.4^{\mathrm{c}}$ & $73.2 \pm 0.9^{\mathrm{c}}$ & $77.9 \pm 1.5^{\mathrm{c}}$ \\
Balada myronivska & $49.8 \pm 0.4^{\mathrm{ab}}$ & $55.7 \pm 0.6^{\mathrm{b}}$ & $54.3 \pm 0.3^{\mathrm{a}}$ & $59.0 \pm 0.7^{\mathrm{b}}$ & $56.2 \pm 1.2^{\mathrm{bb}}$ & $69.8 \pm 2.8^{\mathrm{a}}$ \\
\hline
\end{tabular}

Note: different letters indicate values which reliably differed one from another within one column of the table according to the results of comparison using the ANOVA with Bonferroni correction.

Table 3

Vernalization requirement duration and days to heading in new winter wheat varieties $(x \pm S E, n=90)$

\begin{tabular}{|c|c|c|c|c|c|c|c|}
\hline \multirow[b]{2}{*}{$\begin{array}{c}\text { Genotype of } \\
\text { near-isogenic line }\end{array}$} & \multicolumn{2}{|c|}{2016} & \multicolumn{2}{|c|}{2017} & \multicolumn{2}{|c|}{2018} & \multirow[b]{2}{*}{$\begin{array}{l}\text { Vernalization } \\
\text { requirement }\end{array}$} \\
\hline & $\begin{array}{l}\text { vernalization } \\
\text { requirement }\end{array}$ & $\begin{array}{l}\text { days to } \\
\text { heading }\end{array}$ & $\begin{array}{l}\text { vernalization } \\
\text { requirement }\end{array}$ & $\begin{array}{l}\text { days to } \\
\text { heading }\end{array}$ & $\begin{array}{c}\text { vernalization } \\
\text { requirement }\end{array}$ & $\begin{array}{l}\text { days to } \\
\text { heading }\end{array}$ & \\
\hline Vrd1Vrd1vrd2vrd2 & 30 & $65.3 \pm 1.8^{\mathrm{a}}$ & 30 & $57.4 \pm 2.6^{\mathrm{a}}$ & 40 & $55.9 \pm 0.9^{\mathrm{a}}$ & short duration \\
\hline vrd1 vrd1 Vrd2 Vrd2 & 40 & $72.4 \pm 4.1^{b}$ & 30 & $75.4 \pm 3.0^{b}$ & 40 & $74.8 \pm 2.0^{b}$ & (31-40 days) \\
\hline $\operatorname{vrd} 1 \mathrm{vrd} 1 \mathrm{vrd} 2 \mathrm{vrd} 2$ & 50 & $70.5 \pm 2.5^{\mathrm{ab}}$ & 50 & $72.3 \pm 2.6^{b}$ & 50 & $68.7 \pm 5.2^{\mathrm{b}}$ & $\begin{array}{l}\text { medium duration } \\
\text { (41-50 days) }\end{array}$ \\
\hline
\end{tabular}

Note: see Table 2 .

Table 4

Vernalization requirement duration and days to heading in winter wheat near-isogenic lines $(x \pm S E, n=90)$

\begin{tabular}{|c|c|c|c|c|c|c|c|}
\hline \multirow[b]{2}{*}{$\begin{array}{c}\text { Genotype of } \\
\text { near-isogenic line }\end{array}$} & \multicolumn{2}{|c|}{2016} & \multicolumn{2}{|c|}{2017} & \multicolumn{2}{|c|}{2018} & \multirow[b]{2}{*}{$\begin{array}{l}\text { Vernalization } \\
\text { requirement }\end{array}$} \\
\hline & $\begin{array}{l}\text { vernalization } \\
\text { requirement }\end{array}$ & $\begin{array}{c}\text { days to } \\
\text { heading }\end{array}$ & $\begin{array}{l}\text { vernalization } \\
\text { requirement }\end{array}$ & $\begin{array}{l}\text { days to } \\
\text { heading }\end{array}$ & $\begin{array}{l}\text { vernalization } \\
\text { requirement }\end{array}$ & $\begin{array}{l}\text { days to } \\
\text { heading }\end{array}$ & \\
\hline Vrd1Vrdlvrd2vrd2 & 30 & $65.3 \pm 1.8^{\mathrm{a}}$ & 30 & $57.4 \pm 2.6^{\mathrm{a}}$ & 40 & $59.4 \pm 0.9^{\mathrm{a}}$ & short duration \\
\hline vrd1 vrd1 Vrd2 Vrd2 & 40 & $72.4 \pm 4.1^{\mathrm{b}}$ & 30 & $75.4 \pm 3.0^{\mathrm{b}}$ & 40 & $74.8 \pm 2.0^{b}$ & (31-40 days) \\
\hline vrd1 vrd1 vrd2vrd2 & 50 & $70.5 \pm 2.5^{\mathrm{ab}}$ & 50 & $72.3 \pm 2.6^{\mathrm{b}}$ & 50 & $68.7 \pm 5.2^{\mathrm{b}}$ & $\begin{array}{l}\text { medium duration } \\
\text { (41-50 days) }\end{array}$ \\
\hline
\end{tabular}

Note: see Table 2 .

Table 5

The segregation ratio in $\mathrm{F}_{2}$ population for "heading occurrence: no heading occurrence" after vernalization duration 40 and 30 days

\begin{tabular}{|c|c|c|c|c|c|c|c|c|c|c|}
\hline \multirow{2}{*}{$\begin{array}{c}\text { Days of } \\
\text { vernalization }\end{array}$} & \multirow{2}{*}{ Variety } & \multicolumn{3}{|c|}{ vrd1vrd1vrd2vrd2 } & \multicolumn{3}{|c|}{ Vrd1Vrd1vrd2vrd2 } & \multicolumn{3}{|c|}{ vrd1vrd1Vrd2Vrd2 } \\
\hline & & fact & theoretical & $\chi^{2}$ & fact & theoretical & $\chi^{2}$ & fact & theoretical & $\chi^{2}$ \\
\hline \multirow{4}{*}{30} & Estafeta myronivska & $136: 132$ & $3: 1^{*}$ & 147.14 & $124: 14$ & $15: 1$ & 3.57 & $111: 25$ & $3: 1$ & 3.18 \\
\hline & Hratsiia myronivska & $13: 122$ & $1: 15$ & 2.63 & $118: 28$ & $13: 3$ & 0.02 & $13: 122$ & $1: 15$ & 2.63 \\
\hline & MIP Assol & $0: 143$ & - & - & $161: 27$ & $13: 3$ & 2.38 & $22: 107$ & $3: 13$ & 0.24 \\
\hline & Balada myronivska & $3: 113$ & $1: 15$ & 2.66 & 109:18 & $13: 3$ & 1.74 & 4:136 & $1: 15$ & 2.75 \\
\hline \multirow{4}{*}{40} & Estafeta myronivska & $113: 32$ & $3: 1$ & 0.66 & $146: 16$ & $15: 1$ & 3.63 & $85: 8$ & $15: 1$ & 0.88 \\
\hline & Hratsiia myronivska & $140: 36$ & $3: 1$ & 1.94 & $198: 35$ & $13: 3$ & 2.13 & $130: 11$ & $15: 1$ & 0.58 \\
\hline & MIP Assol & $97: 24$ & $3: 1$ & 1.72 & $213: 48$ & $13: 3$ & 0.02 & $119: 9$ & $15: 1$ & 0.13 \\
\hline & Balada myronivska & $105: 25$ & $3: 1$ & 2.31 & 108:6 & $15: 1$ & 0.19 & $137: 23$ & $13: 3$ & 2.01 \\
\hline
\end{tabular}

Note: $*$-does not correspond to the theoretical segregation ratio; $\chi^{2}<3.84$ at the $\mathrm{P}=0.05$.

Vernalization requirement. In 2016, duration 50 days was considered sufficient vernalization period for the winter wheat varieties Hratsiia myronivska and MIP Assol, as the highest percentage of heading plants was observed in this variant of the experiment (Table 3).

For the varieties Estafeta myronivska and Balada myronivska a high percentage of heading plants was found in the variant with 40 days vernalization. In 2017, plants of the variety Estafeta myronivska had the highest percentage of heading in the variant with vernalization during 50 days $(100 \%)$. However, after 40 days of vernalization duration, heading plants were observed at the level of $70.8 \%$, which makes it possible to consider this particular period to be necessary for transition of plants to generative state. The same period is necessary for plants of wheat varieties Hratsiia myronivska and MIP Assol. In the variety Balada myronivska, the higher percentage of heading plants was observed in both variants, therefore, for this variety, the vernalization requirement was 30 days. Vernalization requirement for the variety Hratsiia myronivska in 2018 was 50 days, because for this vernalization duration heading plants were observed at the level of $70 \%$. Whenever seedlings of this variety were vernalized during 40 and 30 days, the heading occurred only in $47.4 \%$ and $41.2 \%$ of plants, respectively. In the variety MIP Assol $91.7 \%$ of plants were heading at 50 days of vernalization and $65.0 \%$ at 40 days. After 30 days of vernalization duration there was a low percentage of heading plants, so we consider
40 days of vernalization to be sufficient for transition of plants of this variety to the generative state.

The varieties Balada myronivska and Estafeta myronivska required 40 days of vernalization too. They differ from the previous ones in that in the variant with 30 days vernalization most of the plants of these varieties remained at the tillering phase.

The heading dynamic of the varieties under study indicated that the average time to heading varied over the years from 55.9 to 77.9 days. The highest range of variation of this trait among the varieties was observed in 2018, and the lowest was in 2016. The shortest time to heading at the established duration of vernalization of 40 days in 2016 was noted in the varieties Estafeta myronivska and Balada myronivska ( $66.3 \pm 0.26$ and $65.1 \pm 0.50$ days). In 2017 and 2018 the shortest time to heading (59.8 and 59.0 days, respectively) was observed in the variety Hratsiia myronivska.

In varieties with short vernalization requirement duration, this period was, on average, 31-40 days, with medium vernalization requirement duration 41-50 days, and with a long-term - 51-60 days. The results of the research show that the varieties MIP Assol and Hratsiia myronivska require medium vernalization duration (41-50 days), whereas the varieties Estafeta myronivska and Balada myronivska require short vernalization duration (31-40 days). No varieties with long-term vernalization duration were revealed in our research. 
Vernalization duration requirement under environmental conditions of the Ukrainian Forest-Steppe was determined also in winter wheat nearisogenic lines Erythrospermum 604 Vrd1Vrd1vrd2vrd2, Erythrospermum 604 vrd1vrd1Vrd2Vrd2, and Erythrospermum 604 vrd1vrd1vrd2vrd2. In 2016 (Table 4), the lines Erythrospermum 604 with dominant allele of Vrd1 or Vrd2 genes required 30 and 40 days of vernalization duration, because in 70.0 and $63.0 \%$ of plants heading occurred. The line vrdl vrdl vrd2 vrd2 required 50 days of vernalization duration, because in variants 40 and 30 days of vernalization most plants remained at the tillering stage. In 2017, the line Vrd1Vrd1vrd2vrd2, with dominant allele of the Vrd1 gene, at the vernalization of seeds during 50,40, and 30 days demonstrated heading in $100 \%$ of plants. The same level was noted in the line vrdlvrd1Vrd2 Vrd2, which means vernalization duration 30 days was sufficient for it. Heading occurrence for the line vrd1vrd1vrd2vrd2 after 40 days of vernalization duration was noted only in $47 \%$ plants, after 30 days no heading was noted. After 50 days of vernalization duration, heading occurrence was observed in all plants. In 2018, the lines Erythrospermum 604 with dominant alleles of $\operatorname{Vrd} 1$ or $\operatorname{Vrd} 2$ genes required 40 days of vernalization duration, and then heading occurred in 70.6 and $64.0 \%$ of plants, respectively.

For the near-isogenic line Erythrospermum 604 vrd1vrd1vrd2vrd2 being a carrier of recessive allele of these genes, vernalization requirement duration was 50 days, because for shorter vernalization duration (30 and 40 days) no heading was noted. As indicated by heading dynamic for three years, heading time averaged 59.5 days in the line VrdlVrdlvrd2vrd2, 74.2 days in the line vrdlvrd1Vrd2Vrd2 and 70.5 days in the line vrdlvrdlvrd2vrd2. The variation in heading dynamic of the tester lines among the years is explained by differing weather conditions over the years of the research. Since, weather in April and May in 2017 was cooler as compared to these months in 2018, so more plants did not reach heading.

Hybridological analysis. The actual segregation ratio for "heading occurrence: no heading occurrence" in all cross combinations with recessive tester of gene Vrd corresponded to the theoretical 3:1 (Table 5).

The segregation ratio in populations Vrd1Vrd1vrd2vrd2/Estafeta myronivska and vrd1vrd1Vrd2 Vrd2/Estafeta myronivska corresponded to 15:1. The segregation ratio in combinations Vrd1Vrd1vrd2vrd2/Hratsiia myronivska, Vrd1Vrd1vrd2vrd2/MIP Assol and Vrd1Vrd1vrd2vrd2/Balada myronivska was 13:3, and in the population created with these varieties and tester line vrd1vrd1Vrd2Vrd2 it was 15:1. The segregation ratio in combinations Vrd1Vrd1vrd2vrd2/Balada myronivska and vrd1vrd1Vrd2 $\operatorname{Vrd} 2 /$ Balada myronivska was $15: 1$ and 13:3, respectively.

After 30 days vernalization in the population vrd1vrd1vrd2vrd2/Estafeta myronivska the fact segregation ratio for "heading occurrence: no heading occurrence" was 136:132, which did not correspond to the theoretical ratio 3:1. In combinations Vrd1Vrd1vrd2vrd2/Estafeta myronivska and vrd1vrd1Vrd2Vrd2/Estafeta myronivska this ratio was 15:1 and 3:1 respectively. In the combinations of the varieties Hratsiia myronivska and Balada myronivska with the tester of recessive genes (vrd1 vrd1 vrd2vrd2) the fact segregation corresponded to the theoretical ratio $1: 15$ as well as with tester of dominant gene $\mathrm{Vrd} 2$ to the ratio 13:3. In the combination vrd1vrd1vrd2vrd2/MIP Assol even for 90 days segregation was not observed. The segregation ratio with the tester Vrd1Vrd1 vrd2vrd2 was 13:3, and with the tester vrd1 vrd1 Vrd2Vrd2 it was 3:13.

Frost resistance. On average for 2017-2019, the percentage of viable plants of the variety Myronivska 808 after freezing at temperature minus $18{ }^{\circ} \mathrm{C}$ and minus $20^{\circ} \mathrm{C}$ was $87 \%$ and $58 \%$, respectively. Freezing tolerance at the level of the standard variety (according to Fisher's test) at both freezing temperatures was observed in the varieties Hratsiia Myronivska $(79 \pm 4.5,50 \pm 5.5)$ and Balada Myronivska ( $82 \pm 4.4,53 \pm 5.6$, Table 6). The variety Estafeta myronivska significantly exceeded the standard for the percentage of live plants after freezing at minus $18^{\circ} \mathrm{C}(99 \pm 1.2)$, and for the temperature minus $20^{\circ} \mathrm{C}$ - percentage of live plants was at its level $(59 \pm 5.6)$. In the variety MIP Assol percentage of live plants at the freezing temperature minus $18^{\circ} \mathrm{C}$ was of the level of the standard (91\%), and at the minus $20^{\circ} \mathrm{C}$ significantly exceeds the standard.

\section{Discussion}

It has been established that in the conditions of the south of Ukraine the Ppd-Dla allele significantly shortens the duration of time to heading, reduces plant height, reduces the spike and stem length, number of spikes and fertile spikelets per spike, spike density; increases grain number per spike and grain weight per main spike, grain weight of secondary stems, 1000 kernel weight (Bakuma et al., 2018). The genotype Ppd-A1b PpdBlb Ppd-Dla is prevalent in the varieties bred at Bila Tserkva Experimental and Breeding Station, the Ppd-Dla allele determines insensitivity to the photoperiod and promotes an earlier heading date. Only the variety Lehenda bilotserkivska is a carrier of the recessive allele Ppd-Dlb and has a later heading date (Filimonov et al., 2018). In the Ppd-1 gene system of the varieties bred at the Institute of Irrigated Agriculture of NAAS the dominant Ppd-Dla allele there were identified and recessive $b$ alleles were identified in the Ppd-A1 and Ppd-B1 loci (Bakuma et al., 2019). According to the results of our research, we assume that the new varieties of winter bread wheat of breeding at the MIW do not have the dominant allele of the Ppd-D1 gene, because varieties insensitive to the photoperiod were not detected among them.

\section{Table 6}

The percentage of surviving plants of winter wheat varieties after freezing $(\%, \mathrm{x} \pm \mathrm{SE}, \mathrm{n}=80), 2017-2019$

\begin{tabular}{lcc}
\hline \multirow{2}{*}{\multicolumn{1}{c}{ Variety }} & \multicolumn{2}{c}{ Temperature of freezing } \\
\cline { 2 - 3 } & $-18^{\circ} \mathrm{C}$ & $-20^{\circ} \mathrm{C}$ \\
\hline Myronivska 808, standard & $87.0 \pm 3.8^{\mathrm{a}}$ & $58.0 \pm 5.5^{\mathrm{a}}$ \\
Estafeta myronivska & $99.0 \pm 1.2^{\mathrm{b}}$ & $59.0 \pm 5.6^{\mathrm{a}}$ \\
Hratsiia myronivska & $79.0 \pm 4.5^{\mathrm{a}}$ & $50.0 \pm 5.5^{\mathrm{a}}$ \\
MIP Assol & $91.0 \pm 3.2^{\mathrm{a}}$ & $70.0 \pm 5.2^{\mathrm{b}}$ \\
Balada myronivska & $82.0 \pm 4.4^{\mathrm{a}}$ & $53.0 \pm 5.6^{\mathrm{a}}$ \\
\hline
\end{tabular}

Note: different letters indicate values which reliably differed one from another within one column of the table according to the results of comparison using the Fisher's criterion.

Vernalization requirement in wheat can be considered as an adaptive mechanism that provides delay in transition to the reproductive stage of development during winter (Muterko et al., 2015). Analysis of the assortment of winter wheat of Ukrainian breeding showed that among the genotypes created at the Plant Breeding and Genetics Institute - National Centre of Seed and Cultivar Investigation of NAAS the majority of wheat genotypes possessed dominant allele of the Vrd1 gene (54.5\%) (Fayt, 2012). Among the varieties of the Plant Production Institute nd. a. V. Y. Yuriev of NAAS, the majority of genotypes had the dominant allele Vrd3 (36.4\%) or the three recessive vrd genes (36.4\%). At the same time, the possibility of modifying the vernalization duration requirement by Ppd genes is not excluded (Stelmakh et al., 2019; Zubrich \& Avksentieva, 2019). It was noted that introduction into the modern enhanced in productivity wheat gene pool of genetic material relating to the rates of initial development typical for varieties of past generations would improve the adaptive properties of future breeding material (Stelmakh \& Fayt, 2015).

The segregation in F2 population for heading occurrence resulting from hybridological analysis (Fayt, 2006b, 2012) was not observed if the genotype of the variety and the tester coincided. When crossing a variety that is assumed to have dominant gene $\operatorname{Vrd} 1, \operatorname{Vrd} 2$ or $\operatorname{Vrd} 3$ with a recessive tester after 40 days of vernalization, the segregation ratio is $3: 1$. If in the genotype of the variety there are two dominant genes of vernalization requirement at the same time, the segregation ratio is 15:1. The segregation ratios of 3:1 and 15:1 indicate a difference in genes in the variety and tester studied. It was determined that the vernalization requirement duration of Vrd gene testers in the Right-bank Forest-Steppe of Ukraine was $30-50$ days. So, to reveal differences among genotypes in this agroclimatic zone 30 and 40 days are sufficient terms of vernalization.

In our case, after 30 days vernalization in the population vrdlvrd1 $\operatorname{vrd} 2 \mathrm{vrd} /$ Estafeta myronivska the fact segregation ratio for "heading occurrence : no heading occurrence" was 136:132, which did not correspond to the theoretical ratio $3: 1$, which could have been caused by weather conditions, at the same time it indicates the difference between the variety studied and the tester. In the combination vrdlvrd1vrd2vrd2/MIP Assol on the date of the last accounting 20 plants remained at tubing stage, and a significant number (123 plants) remained at the tillering stage The obtained results of plant accounting in this combination indicate the significant influence of weather conditions on plant development, because at 40 days of vernalization many of the plants reached heading, and the average time 
to heading was 80 days. Taking this into account, we can assume that the plants of this hybrid combination could reach heading after 93-94 days with corresponding theoretical segregation ratio of 1:3.

Theoretical segregation at 40 days of vernalization in the combinations with testers Vrd1Vrd1vrd2vrd2 and vrd1vrd1Vrd2Vrd2 in the ratio "heading occurrence: no heading occurrence" 13:3 in the varieties Hratsiia myronivska, MIP Assol and Balada myronivska is probably caused by different photoperiod sensitivity. The influence of weather conditions on the segregation pattern in hybrid populations has also been noted in earlier publications (Fayt, 2006b). Comparing the results of hybridological analysis obtained (Table 5) with the theoretically expected segregation ratio, we assume that in the varieties Estafeta myronivska, Hratsiia myronivska, MIP Assol and Balada myronivska the vernalization requirement duration is controlled by a gene (genes) other than Vrd1 and Vrd2.

Despite climate change, development of winter wheat varieties with increased frost tolerance is still one of the main tasks of scientific institutions not only in Ukraine but also abroad (Riabchun, 2012; Lytvynenko, 2016; Bulavka et al., 2018; Cherenkov et al., 2018; Grabovets, 2019). It is established that the level of frost tolerance in winter wheat varieties bred by institutions in the Forest-Steppe of Ukraine varies from $74.5 \%$ to 90.8\% (Golyk et al., 2017). In our research we have found that newly developed winter wheat varieties at MIW with increased productive and adaptive potential in the Forest-Steppe of Ukraine are characterized by medium photoperiod sensitivity as well as medium and short vernalization requirement duration. Moreover, frost tolerance of these varieties is at the level and above the variety Myronivska 808 , which is highly tolerant to low temperatures.

\section{Conclusion}

It was determined that winter wheat varieties Estafeta myronivska, Hratsiia myronivska, MIP Assol and Balada myronivska developed at MIW in recent years with increased productive and adaptive potential in the conditions of the Central part of the Ukrainian Forest-Steppe are characterized with medium photoperiod sensitivity, and medium or short vernalization requirement duration. We didn't establish the presence of Vrd1 and Vrd2 genes in these varieties. At the same time, the genetically determined frost tolerance of the varieties studied is at the level and above the variety Myronivska 808 , which is highly tolerant to low temperatures. Our results indicate the possibility to recombine in the genotype different levels of manifestation of these traits by selection and to develop varieties with their optimal combination for certain ecological conditions. This is of great practical importance in farming, as the increase in the share of sown areas of crops harvested late (corn, sunflower, etc.) in the Central part of the Forest-Steppe of Ukraine in recent years has caused a shift in winter wheat sowing dates to later. Under such conditions, the varieties mentioned above can undergo sufficient hardening, meet their vernalization requirement and form a high level of winter hardiness. The relatively medium level of photoperiod sensitivity allows the vegetation to be restored a little earlier in spring and winter reserves of moisture to be used more effectively.

\section{References}

Bakuma, A. O., Bulavka, N. V., \& Chebotar, S. V. (2016). Genotypy novykh Myronivskykh sortiv ozymoji pshenytsi za genamy Ppd-A1, Ppd-D1 ta jikh fotoperiodychna chutlyvist [The genotypes of modern Myronivsky varieties of winter wheat for Ppd-A1, Ppd-D1 genes and their sensitivity to photoperiod]. Odessa National University Herald, Biology, 21(1), 75-88 (in Ukrainian).

Bakuma, A. O., Chebotar, G. O., Lavrynenko, Y. O., \& Chebotar, S. V. (2019). Alelnyi stan geniv system Ppd-1 ta Vm-1 u sortiv ozymoi viakoi pshenytci Instytutu zroshuvanogo zemlerobstva NAAN Ukrainy [Allelic status of the gene Ppd-1 and $\mathrm{Vm}-1$ genetic systems in winter wheat varieties of the Institute of Irrigated Agriculture of NAAS Ukraine]. Odessa National University Herald, Biology, 24(1), 49-64 (in Ukrainian).

Bakuma, A. O., Popovych, Y. A., Motsnyy, I. I., Chebotar, G. O., \& Chebotar, S. V. (2018). Vplyv alelya Ppd-Dla na tempy rozvytku ta agronomichni oznaky pshenytci, vuznachenyy iz zastosuvannyam liniy-analogiv [Effects of the Ppd-D1a allele on growth rates and agronomical traits in wheat detected by the application of analogous lines]. Cytology and Genetics, 52(5), $28-40$ (in Ukrainian).
Balashova, I. A., Fayt, V. I., Zavesha, E. K., \& Sivolap, Y. M. (2006). Markirovanie gena Vrd1 u pshenitsi miagkoy ozimoy [Marking of the Vrd1 gene in the bread winter wheat]. Cytology and Genetics, 40(6), 11-14 (in Russian).

Blyzniuk, B. V., Los, R. M., Demydov, O. A., Kyrylenko, V. V., Humeniuk, O. V., \& Daniuk, T. A. (2019). Vplyv pohodnikh umov na tryvalist okremykh periodiv vegetatsii ta vrozhainist pshenytsi miakoi ozymoi u Lisostepu i Polissi [The influence of weather conditions on duration of particular vegetation periods and yield of bread winter wheat in Forest-Steppe and Polissia]. Myronivka Bulletin, 8, 73-90 (in Ukrainian).

Bulavka, N. V., Yurchenko, T. V., Kucherenko, O. M., \& Pirych, A. V. (2018). Sorty pshenytsi miakoyi ozymoyi, stiyki do vplyvu negatyvnykh chunnykiv dovkillia [Soft winter wheat varieties with resistance to negative environmental factors]. Plant Varieties Studying and Protection, 14(3), 255-261 (in Ukrainian).

Cherenkov, A. V., Gruzinov, S. K., \& Kobos, I. O. (2018). Vplyv peredposivnoi obrobky nasinnia na morozo- ta zymostiikist pshenycja ozymoi pislia riznykh poperednykiv [Influence of pre-seed treatment of seeds on frost and winter resistance of winter wheat after various predecessors]. Grain Crops, 2(1), 53-60 (in Ukrainian).

Cockram, J., Norris, C., \& O’Sullivan, D. M. (2009). PCR-based markers diagnostic for spring and winter seasonal growth habit in barley. Crop Science, 49(2), 403-410.

Deng, W., Casao, M. C., Wang, P., Sato, K., Hayes, P. M., Finnegan, E. J., \& Trevaskis, B. (2015). Direct links between the vernalization response and other key traits of cereal crops. Nature Communication, 6, 5882.

Distelfeld, A., Li, C., \& Dubcovsky, J. (2009). Regulation of flowering in temperate cereals. Current Opinion in Plant Biology, 12, 1-7.

Emtseva, M. V., Efremova, T. T., \& Arbuzova, V. S. (2013). Vliianie allelei VmBla i Vm-B1c na prodolzhitelnost faz razvitiia zamechonnykh i izohennykh linii miahkoy pshenitsy [The influence of Vrn-B1a and Vm-B1c alleles on the length of developmental phases of substitution and near-isogenic lines of common wheat]. Russian Journal of Genetics, 49(5), 545-552 (in Russian).

Erath, W., Bauer, E., Fowler, D. B., Gordillo, A., Korzun, V., Ponomareva, M., Schmidt, M., Schmiedchen, B., Wilde, P., \& Schen, C. (2017). Exploring new alleles for frost tolerance in winter rye. Theoretical and Applied Genetics, 130, 2151-2164.

Fayt, V. I. (2003). Geneticheskaia sistema kontrolia razlichii po prodolzhitelnosti iarovizatsii u ozimoy miahkoyi pshenitsi [Genetic control system of the differences in duration of vemalization in winter common wheat]. Cytology and Genetics, 37(5), 57-64 (in Russian).

Fayt, V. I. (2006a). Izogennye linii ozimoy miahkoy pshenicy po genam kontrolia prodolzhitelnosti jarovizatsii [Near-isogenic lines on the genes controlling differences in duration of vemalization in winter common wheat]. The Herald of Vavilov Society for Geneticists and Breeding Scientists, 10(3), 580-586 (in Russian).

Fayt, V. I. (2006b). Geneticheskii control prodolzhitelnosti yiarovizatsii sortov ozimoy pshenitsy [Genetic control of vernalization requirement duration of winter wheat cultivars]. Ecological Genetics, 4(2), 29-36 (in Russian).

Fayt, V. I. (2007). Efecty kontrolia prodolzhitelnosti iarovizatsii (Vrd) po agronomicheskim priznakam u ozimoy miagkoy pshenitsy [Effects of vernalization duration control genes (Vrd) on agronomical traits in winter bread wheat]. Cytology and Genetics, 41(5), 18-26 (in Russian).

Fayt, V. I. (2012). Identyficatsiia genofondu ozymoy miakoy pshenitsy (Triticum aestivum $\mathrm{L}$.) za genamy tryvalosti potreby v iarovyzatsii (Vrd) [Identification of winter bread wheat (Triticum aestivum $\mathrm{L}$.) gene pool for the genes of vernalization requirement duration (Vrd)]. Plant Genetic Resources, 10/11, 212-219 (in Russian).

Fayt, V. I., Balashova, I. A., Fedorova, V. R., \& Balvinska, M. S. (2014). Identificatciya genotipov Ppdl sortov psenitsi metodami geneticheskoho i STS-PCR analiza [Identification of bread wheat Ppdl-genotypes by hybridological and STS-PCR analysis]. Plant Physiology and Genetics, 46(4), 325-336 (in Russian).

Fayt, V. I., Symonenko, L. K., Mokanu, N. V., \& Popova, N. V. (2007). Hromosomnaya lokalizatsiya genov prodolzhitelnosti perioda yarovizatsiyi (Vrd) u ozimoy miahkoy pshenitsy [Chromosomal location of genes for vernalization requirement duration (Vrd) in winter bread wheat]. Russian Journal of Genetics, 43(2), 143-148 (in Russian).

Fayt, V., Pogrebniuk, O., \& Stelmakh, A. (2017). Identifikatsija ta efekty aleliv gena Vrd2 za hospodarsko cinnymy oznakamy pshenicy v umovakh Pivdennogo stepu Ukrainy [Identification and effects of alleles of gene Vrd2 according to economically valuable attributes of wheat in conditions of South Steppe of Ukraine]. Bulletin of Agricultural Science, 95(6), 41-47 (in Ukrainian).

Filimonov, V. M., Bakuma, A. A., Chebotar, G. A., Burdenyuk-Tarasevich, L. A., \& Chebotar, S. V. (2018). PLR-analiz geniv fotoperiodychnoi chutlyvosti u sortiv mjakoyi ozymoyi pshenyci selektciyi Bilotserkivskoyi doslidno-selektciynoyi stanciyi [PCR-analysis of photoperiod sensitivity genes in bread wheat varieties from Bilatserkovska Experimental Breeding Station]. The Bulletin of Ukrainian Society of Geneticists and Breeders, 16(2), 217-226 (in Ukrainian).

Francia, E., Barabaschi, D., Tondelli, A., Laido, G., Rizza, F., Stanca, A. M., Busconi, M., Fogher, C., Stockinger, E. J., \& Pecchioni, N. (2007). Fine mapping of a 
HvCBF gene cluster at the frost resistance locus Fr-H2 in barley. Theoretical and Applied Genetics, 115, 1083-1091.

Golyk, L., Starychenko, V., Kobernyk, N., Guba, I., \& Klymenko, I. (2017). Features of winter resistance of collections samples of winter wheat in the conditions of the Northern Forest-Steppe. Plant and Soil Science, 269, 126-136.

Grabovets, A. I., \& Fomenko, M. A. (2019). Plus-transgression in winter wheat breeding on frost resistance and productivity. Russian Agricultural Sciences, 45, $407-411$.

Guedira, M., Malony, P., Xiong, M., Petersen, S., Murphy, J. P., Marshall, D., Johnson, J., Harrison, S., \& Brown-Guedira, G. (2014). Vernalization duration requirement in soft winter wheat is associated with variation at the VRN-B1 locus. Crop Science, 54(5), 1960-1971.

Jones, H. E., Lukac, M., Brak, B., Martinez-Eixarch, M., Alhomedhi, A., Cooding, M. J., Wingen, L. U., \& Griffiths, S. (2017). Photoperiod sensitivity affects flowering duration in wheat. The Journal of Agricultural Science, 155, 32-43.

Kawakita, S., Ishikawa, N., Takahashi, H., Okuno, R., \& Takahashi, T. (2020). Winter wheat phenological development model with a vernalization function using sigmoidal and exponential functions. Journal of Agricultural Meteorology, 76(2), 81-88.

Kiss, T., Balla, K., Veisz, O., Lang, L., Bedo, Z., Griffiths, S., Isaac, P., \& Karsai, I. (2014). Allele frequencies in the VRN-A1, VRN-B1 and VRN-D1 vernalization response and PPD-B1 and PPD-D1 photoperiod sensitivity genes, and their affects on heading a diverse set of wheat cultivars (Triticum aestivum L.). Molecular Breeding, 34, 297-310.

Koemel, J., Guenzi, A., Anderson, J., \& Smith, E. (2004). Cold hardiness of wheat near-isogenic lines differing in vernalization alleles. Theoretical and Applied Genetics, 109(4), 839-846.

Kristensen, K., Schelde, K., \& Olesen, J. E. (2011). Winter wheat yield response to climate variability in Denmark. The Journal of Agricultural Science, 149, $33-47$.

Law, C. N., Sutka, J., \& Worland, A. J. A genetic study of day - length response in wheat (1978). Heredity, 41(2), 185-191.

Li G., Yu, M., Fang T., Cao, S., Carver, B. F. \& Yan, L. (2013). Vernalization requirement duration in winter wheat is controlled by $\mathrm{TaVm}-\mathrm{A} 1$ at the protein level. The Plant Journal, 76(3), 742-753.

Lytvynenko, M. A. (2016). 100 rokiv rozvytku selektsiynykh prohram psenytsi ozymoi [100-years history of the development of bread winter wheat breeding programs]. Plant Varieties Studying and Protection, 2(31), 75-82 (in Ukrainian).

McIntosh, R. A., Yamazaki, Y., Dubcovsky, J., Rogers, J., Morris, C., Appels, R., \& Xia, XC. (2013). Catalogue of gene symbols for wheat. 12th International Wheat Genetics Symposium. Paestum(Italy), 31

Muterko, A. F., Balashova, I. A., Fayt, V. I., \& Sivolap, Yu. M. (2015). Molekulyarno-genetychni mekhanismy regulyatsii typu rozvytku pshenytsi [Moleculargenetc mechanisms regulation of growth habit in wheat]. Cytology and Genetics, 49(1). 71-86 (in Ukrainian).

Pankova, K., \& Kosner, J., (2004). Chromosome substitutions with dominant loci Vm-1 and their effect on developmental stages of wheat. Czech Journal of Genetics and Plant Breeding, 40(2), 37-44.

Prasil, I. T., Prasilova, P., \& Pankova, K. (2004). Relationships among vernalization, shoot apex development and frost tolerance in wheat. Annals of Botany, 94(3), 413-418.

Pugsley, A. T. (1971). A genetic analysis of the spring-winter habit of growth in wheat. Australian Journal of Agricultural Research, 22(1), 21-23.

Pugsley, A. T. (1972). Additional genes inhibiting winter habit in wheat. Euphytica, 21, 547-552.

Royo, C., Dreisigacker, S., Soriano, J. M., Lopes, M., Ammar, K., \& Villegas, D. (2020). Allelic variation at the vernalization response (Vm-1) and photoperiod sensitivity (Ppd-1) genes and their association with the development of durum wheat landraces and modern cultivars. Frontiers in Plant Science, 11, 838.

Ryabchun, N. I. (2012). Formuvannja oznakovykh kolektsiy ta kolektsiy sortiv-etaloniv za oznakoyu zymostiykosti u ozymykh zlakiv [Forming trait collections and collections of varieties-standards on the basis of winter hardiness in winter cereals]. Plant Breeding and Seed Production, 101, 247-253.

Rybas, I. A., Marchenko, D. M., Nekrasov, E. I., Ivanisov, M. M., Grichanikova, T. A., \& Romanyukina, I. V. (2018). Otsenka parametrov adaptivnosti sortov ozimoy miagkhoy pshenitsy [Assesment of parameters of winter soft wheat adaptability]. Grain Economy of Russia, 4, 51-54 (in Russian).

Sandve, S., Kosmola, A., Rudi, H., Fjellheim, S., Rapacz, M., Yamada, T., \& Rognli, O. (2011). Molecular mechanisms underlying frost tolerance in perennial grasses adapted to cold climates. Plant Science, 180(1), 69-77.

Stelmakh, A. F. (1992). Genetic effects of Vrn genes on heading date and agronomic traits in bread wheat. Euphytica, 65, 53-60.

Stelmakh, A. F., \& Fait, V. I. (2015). Systemy kontroliu pochatkovoho rozvytku suchasnykh selektsiinykh zrazkiv ozymykh zemovykh kultur u SGI-NCNS [Systems of initial development control in modern cereal breeding speciment PBGI-NCSCI]. Factors in Experimental Evolution of Organisms, 16, 156-160 (in Ukrainian).

Stelmakh, A. F., \& Fait, V. I. (2019). Osoblyvosti tempiv pochatkovoho rozvytku novukh evropeiskykh sortiv ozymoyi pshenytsi miakoyi u zviazku z systemamy geniv Ppd-1 ta Vrd [Related to Ppd-1 and Vrd gene systems peculiarities of initial development rate in new European winter bread wheat cultivars]. Factors in Experimental Evolution of Organisms, 24, 166-171 (in Ukrainian).

Stelmakh, A. F., \& Herasymenko, V. P. (2008). Dialelnyi analiz daty kolosinnja ozymoyi mjakoyi pshenyci pry varijuvanni jarovyzaciyi ta fotoperiodu [Diallel analisys of date heading of bread winter wheat at the variations vernalization and photoperiod]. Plant Breeding and Seed Production. 96, 244-251 (in Ukrainian).

Stelmakh, A., Zolotova, N., \& Fayt, V. (2005). Genetic analysis of differences in duration vernalization requirement of winter bread wheat. Cereal Research Communications, 33(4), 713-718.

Sutka, J. (2001). Genes for frost resistance in wheat. Euphytica, 119, 169-177.

Sutton, F., Chen, D.-G., Ge, X., \& Kenefick, D. (2009). Cbf genes of the Fr-A2 allele are differentially regulated beetwen long-term cold acclimated crown tissue of freeze-resistant and -susceptible, winter wheat mutant lines. BMC Plant Biology, $9,34$.

Syvolap, Y. M., Balashova, I. A., \& Fayt, V. I. (2007). Identyficatsiia genotypiv ozumoyi miakoyi psenytsi z korotkym terminom yarovuzatsiynoyi potreby [Identification genotypes of bread winter wheat with shot period of vernalization requirement duration]. Odesa (in Ukrainian).

Toptikov, V. A., \& Chebotar, S. V. (2019). Genetyko-biokhimichni aspekty zvjazku alelnoho skladu lokusu Ppd-D1 i stiykosti ozymoi pshenyci do nyzkoi temperatury [Genetic and biochemical aspects of the association of the Ppd-D1 locus with the resistance of winter soft wheat to low temperature]. Odesa National University Herald, Biology, 24(2), 11-37 (in Ukrainian).

Whittal, A., Kaviani, M., Graf, R., Humphrey, G., \& Navabi, A. (2018). Allelic variation of vernalization and photoperiod response genes in a diverse set of North American high latitude winter wheat genotypes. PLoS One, 13(8), e0203068.

Worland, A. J. (1996). The influence of flowering time genes on environmental adaptability in European wheats. Euphytica, 89, 49-57.

Worland, A. J., Borner, A., Korzun, V., Li, W. M., Petrovic, S., \& Sayers, E. J. (1998). The influence of photoperiod genes on the adaptability of European winter wheats. Euphytica, 100, 385-394.

Yan, L., Fu, D., Li, C., Blechl, A., Tranquilli, G., Bonafedl, M., Sanchez, A., Valarik, M., Yasuda, S., \& Dubcovsky, J. (2006). The wheat and barley vernalization gene Vrn-3 is an orthologue of FT. Proceedings of the National Academy of Sciences of the United States of America, 103(51), 19581-19586.

Yang, F. P., Zhang, X. K., Xia, X. C., Laurie, D. A., Yang, W. X., \& He, Z. H. (2009). Distribution of the photoperiod insensitive Ppd-D1a allele in Chinese wheat cultivars. Euphytica, 165(3), 445-452.

Yoshida, T., Nishida, H., Akashi, Y., Kato, K., Zhu, J., Nitcher, R., Distelfeld, A., \& Dubcovsky, J. (2010). Vm-D4 is a vernalization gene located on the centromeric region of chromosome 5D in hexaploid wheat. Theoretical and Applied Genetics, $120(3), 543-552$.

Zubrich, O. I., \& Avksentieva, O. O. (2019). Vplyv fotoperiodu na morphogenetychni procesy u izogennykh za genamy PPD liniyi pshenytsi mjakoyi [Influence of photoperiod on morphogenetic processes in near-isogenic lines in Ppd genes of soft wheat]. Factors in Experimental Evolution of Organisms, 24, 302-307 (in Ukrainian). 